\title{
Eye Movement Desensitization and Reprocessing (EMDR) Therapy for Handling Post Traumatic Stress Disorder (PTSD) Respondents
}

\author{
Eka Susanty, Setyono Koesno, and Candra Yudhistira \\ Faculty of Psychology \\ Universitas Jenderal Achmad Yani
}

\author{
Lulu Lusianti \\ Sekolah Ilmu dan Teknologi Hayati \\ Institut Teknologi Bandung
}

\author{
Suprijanto \\ Fakultas Teknologi Industri \\ Institut Teknologi Bandung
}

\begin{abstract}
EMDR therapy is designed to reduce distress related traumatic event. PTSD prevalence is large enough in Indonesia. It was caused by many natural disasters that happened in several area of Indonesia. However, the application of EMDR for reducing PTSD symptoms was still rare. The objective of this study was to examine the intervention of EMDR therapy in handling PTSD respondents and using a one group pretest-posttest design. There were nine PTSD respondents involved during treatment. EMDR treatments were conducted in four repetitive sessions. Each session was completed in 60-90 minutes. Data was taken using PSS (PTSD Symptom Scale) and tested with Wilcoxon statistical analysis. The statistic test showed $(Z=-2.668 ; p=.05)$ with Asymp. Sig. $=.008$. Descriptive data showed that mean scores before and after therapy are 30.88 and 15.77 respectively. This research concluded that EMDR therapy can work to decrease PTSD symptoms.
\end{abstract}

Keywords: eye movement desensitization and reprocessing (EMDR), posttraumatic stress disorder (PTSD), neurocognitive

Terapi EMDR dirancang untuk menghilangkan distres yang berkaitan dengan adanya pengalaman traumatik. Prevalensi kemunculan gangguan PTSD di Indonesia cukup besar mengingat Indonesia adalah negara rawan bencana yang merupakan sumber stres traumatik. Namun, penggunaan terapi EMDR dalam menangani kasus PTSD belum banyak diterapkan di Indonesia. Adapun tujuan penelitian ini adalah untuk menguji intervensi terapi EMDR dalam menangani naracoba yang terindikasi PTSD. Penelitian ini menggunakan desain one group pretest-posttest design, dengan menggunakan sembilan orang naracoba korban bencana yang terindikasi mengalami PTSD. Selanjutnya diberikan terapi EMDR sebanyak empat kali sesi (pertemuan). Pengukuran kondisi naracoba pada saat pra-uji dan pasca-uji dilakukan dengan menggunakan alat ukur PSS (PTSD Symptom Scale) kemudian dilakukan analisis uji statistik Wilcoxon. Berdasarkan uji beda Wilcoxon diperoleh nilai $(Z=-2.668, p=.05)$ dengan Asymp. Sig. $=.008$. Nilai rata-rata skor setelah dan sebelum terapi EMDR adalah 30.88 dan 15.77. Penelitian ini menunjukkan terapi EMDR yang digunakan dalam penanganan PTSD berhasil menurunkan gejala-gejala PTSD.

Kata kunci: desensitisasi gerak mata dan pemrosesan ulang, post traumatic stress disorder (PTSD), neurokognitif.

EMDR is an integrated neurocognitive therapy that includes neurological sensitivity and cognitive schema. EMDR therapy is designed to reduce trauma-related distress. The prevalence of PTSD in Indonesia is quite large, considering how prone the country is to experi-

This article has been presented at the Neuropsychology National Conference in Universitas Gadjah Mada, Yogyakarta on 30 October 2014.

Correspondence concerning this article should be addressed to Eka Susanty, Faculty of Psychology, Universitas Jenderal Achmad Yani, Jalan Sudirman Canal, PO Box 148, Cimahi 40285, Indonesia.

E-mail: eka.susanty@gmail.com encing natural disasters, a source of traumatic distress. However, the use of EMDR therapy to handle PTSD cases is still quite rare.

Some studies support the effectiveness of EMDR in reducing PTSD symptoms. The main characteristic of a PTSD symptom is divided into three categories: re-experiencing (experiencing or recalling memories of the incident), avoidance (avoiding various stimuli that act as cues to recall the traumatic incident), and hyperarousal (irritability, easily stimulated, restless 
ness). According to Mason et al. (2002, as cited in Taylor, 2006), those who suffer from Post Traumatic Stress Disorder experience a change in the brain structure, including the amygdala and hippothalamuspituitary-adrenal axis. They show variations in cortisol patterns similar to increased levels of norephinephrine, ephinephrine, testosterone, and thyroxine.

Shapiro (1995) suggested the Adaptive Information Processing model, which stated that when information related to the traumatic incident are not processed fully, then distorted perception, emotion, and initial cognition will be stored exactly as experienced during the incident. A person experiencing a traumatic incident will have an imbalance in the nervous system, thus experiencing a change in neurotransmitter and adrenaline levels amongst other things. With the imbalance, the nervous system may not function well and thus information received during the incident, including image, sound, affect and physical sensations will be neurologically disruptive. Distress-inducing traumatic incident will then create a specific excitatory condition that continues to be triggered by internal and external stimuli, expressed as nightmares, flashbacks, and cognitive disruptions, creating symptoms of PTSD.

In the therapy procedure of EMDR, stimuli were given through 'dual stimulation' finger movement followed by therapist eye movement to stimulate physiological mechanism activating information processing system. At the same time, client will be asked to recall memories triggering the incident and bad emotions, and then to reprogram those incidents into a positive believe that will hopefully trigger cognitive processes that can reduce traumatic disorders.

Studies showed that EMDR is effective in handling PTSD. Research by Ironson et al., (2002) showed that EMDR is effective in reducing PTSD symptoms. This is corroborated by the results from Raboni, Tufik, \& Sucheki (2006), regarding the use of EMDR to treat PTSD symptoms of male and female victims of kidnapping, increasing sleep quality, life quality, and perceptions about stress. Clinical results of studies regarding the treatment of war veterans also showed evidence of EMDR's effectiveness on treating PTSD sufferers with anger, guilt, and shame symptoms (Nacash et al., 2007). Based on the study by Ironson, Freund, Strauss, and Williams (2002), it was found that EMDR gave efficient, positive effects with minimal therapy sessions. EMDR was found to reduce PTSD symptoms in three to five symptoms. The researcher of the present study has also done a study on earthquake victims in Pangalengan village, West
Java. Results showed a decrease of PTSD symptoms from moderate to light category on three of four people who were given EMDR therapy (Susanty, Albanik, \& Prathama, 2012).

From the studies described earlier, it was established that EMDR can reduce PTSD symptoms. According to Shapiro (1995), in the EMDR procedure, the use of therapist finger movement to guide client's eye movement is similar to eye movement saccades that occur during REM sleep (rapid eye movement), however there was no clear explanation on how such eye movement could reduce PTSD symptoms. Another hypothesis stated that the eye movement stimulation is related to working memory. Maxfield, Melnyk, and Hayman (2008) explained the effect of eye movement within the context of working memory theory. Working memory is a memory system involved in short-term storage and information manipulation. It has a limited capacity. Research has consistently found that a person's performance will decrease when doing two tasks that simultaneously requires the use of working memory. When the client is doing eye movement and simultaneously focusing on the image of the incident, the quality of the image will reduce and consequently the level of fear and emotion will decrease.

Eye movement stimulation was further explained to give better effect compared to tapping stimulus or other alternatives. Brown and Wesley (2013) explained that tapping only requires spatial processing while eye movement requires both visual and spatial processing. In this case, external stimulus (bilateral stimulus) competes with the recalled image of episodic memory during processing. The decrease of emotional tension was assumed to be a result of the decreased quality of the recalled image.

From the explanations earlier, the researcher is interested to test EMDR therapy intervention in decreasing symptoms of PTSD symptoms.

\section{Adaptive Information Processing Model}

Eye Movement Desensitization and Reprocessing (EMDR) is an integrative and comprehensive psychotherapy approach developed by Shapiro (1995). Shapiro developed the Adaptive Information Processing (AIP) model as a theoretical base and working principle of EMDR therapy. AIP elaborated the effects of EMDR therapy by describing an innate physiological system that helps to transform disruptive information into adaptive resolution through psychological integration of information. 


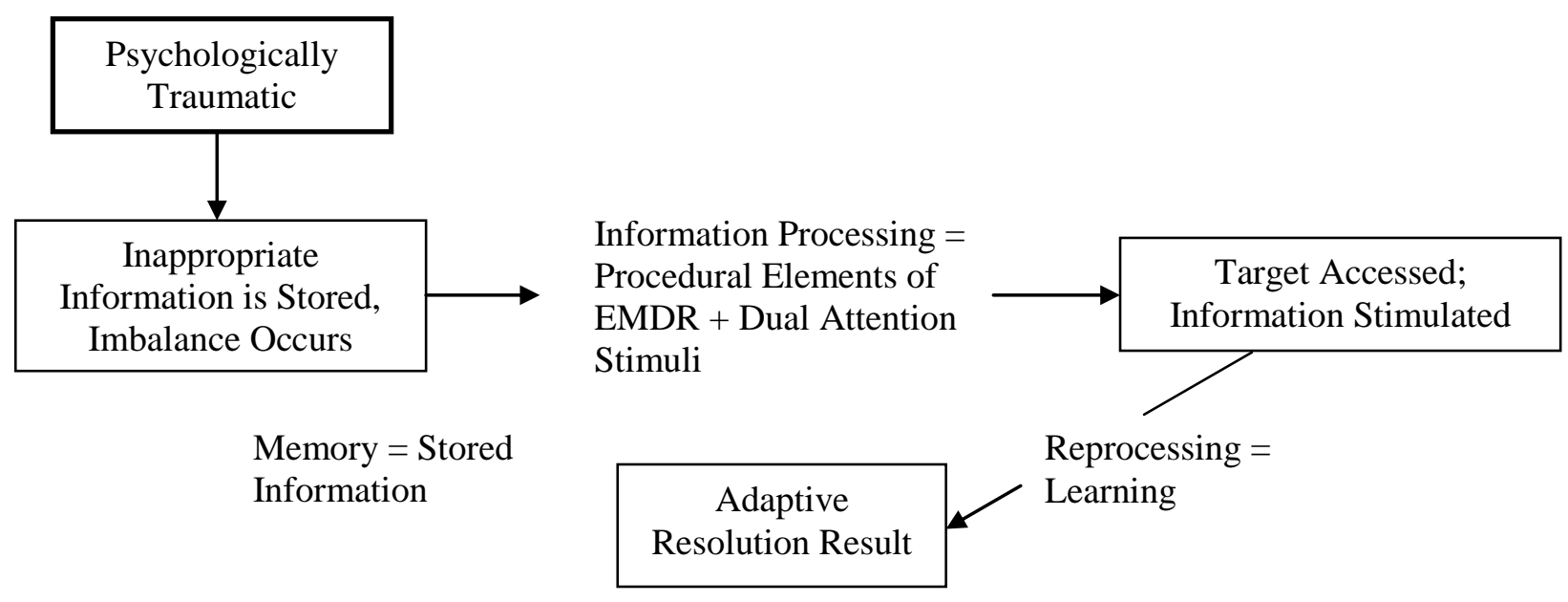

Figure 1. Adaptive information processing model (Hensley, 2009, p. 8).

Based on this model, memory is a component established by perception, attitude and behavior. Memory consists of stored information such as sensory information (received through the sensory system), thoughts, emotions, and beliefs. Shapiro stated that traumatic incidents are the main source of psychological dysfunction. When trauma occurs, it creates disturbance in the information processing system, abandoning associations in sight, hearing, thought, or feelings that are not processed. There is inadequate processing in the central nervous system, and therefore maladaptive responses such as flash-backs or nightmares can be triggered by stimulus that is similar to the traumatic incident.

When traumatic incidents or disruptions occur, information can be stored in the central nervous system in a very specific condition (negative cognition belief, negative emotions and physical sensations experienced by clients during the incident are stored in the central nervous system as if a new traumatic incident is actually occurring). Through processing traumatic memory, EMDR helps clients to generalize positive cognitions and affect, associating them to memories found in the memory network to produce appropriate behavior.

In traumatic incidents, strong emotional levels interrupt a person's ability to process the experience so that the incident becomes "frozen in time". Recall of the traumatic incidents makes it possible for the individuals to re-experience what they felt because images, smell, sounds, and feelings are still stored (present) and are able to be triggered in the current situation. When activated, those memories have negative impacts on daily functioning and can disrupt how we think and relate to other people.
Eye movement (or alternative stimulus) used in EMDR triggers a physiological mechanism that activates the information processing system. The EMDR method involves recalling stressful events and reprogramming them into positive memories, selection of conscious belief, through rapid eye movements to facilitate the process. EMDR involves elements of cognitive behavior therapy with bilateral eye movements or other rhythmic movements, with a left to right stimulation. The key element of EMDR is "dual stimulation". During treatment, clients will be asked to think or describe memories that could trigger the incidents and unhappy emotions, while simultaneously focusing on the therapist's finger movement going backwards and forwards across the client's line of sight. The following is a diagram depicting how EMDR processes traumatic conditions:

\section{EMDR Therapy Procedure}

EMDR treatment consists of eight stages. Each stage focuses on different treatment aspects, as described in the following section by Shapiro (2002):

1. Client history and treatment planning. In this stage the therapist will gather necessary information design the treatment. This includes information about the client's clinical condition, including emotional and physical sensation that felt disruptive. The therapist then sets specific targets that need to be met, including trauma-inducing incident, present situation that could trigger symptoms and the types of positive attitude and behavior needed for the future.

2. Preparation. This phase includes efforts to create therapeutic bond with the client, explanation of EMDR and its effects, focusing the client's atten- 
tion and teaching self-care techniques so that the client can handle negative emotions arising during or in-between therapy sessions, for example relaxation techniques. This session is important to build trust with the client. The therapist should also explain EMDR in more detail in terms of theory and procedure that is about to be carried out.

3. Assessment. In this stage, the therapist identifies target component by asking three things:

a. Visual image representing the target incident, to clarify the visual image of the experienced trauma.

b. Negative thoughts or belief that expresses the client's maladaptive condition. Client will then be asked to indicate the validity of his/her positive thoughts on a scale of 1 to 7 based on Validity of Cognition (VOC). c. Client will also be asked to describe the felt emotional disruption when he/she has to focus on the traumatic visual image by indicating its intensity from a scale of 0 to 11 based on the Subjective Units of Disturbance (SUD).

4. Desensitization. Client will focus his/her attention on every disruptive, negative feelings and emotions as well as physical sensations that arise when focusing on the target image while following the therapist's finger moving backwards and forwards in front of the client's eyes. The client will also be asked to note every reaction during the therapy process: good, bad, or neutral, including the occurrence of insights, associations, or emotions felt.

5. Installation. In this phase, clients will be asked to focus on positive thoughts that have been identified to substitute negative thoughts and beliefs about the trauma. The aim is to strengthen positive beliefs or self statements until the client fully accepts them.

6. Body scan. After replacing negative thoughts about the trauma with a more positive belief, on the next phase the client focuses on various physical sensations on their whole body to detect residual tension. Such residual tension or physical discomfort will then be targeted and consequently extinguished with bilateral stimulation.

7. Closure. Client needs to state emotional stability at the end of every session, whether or not reprocessing occurs. The therapist will then remind the client that disruptive image, thoughts or emotions can arise between sessions. The therapist will also review visualization and relaxation techniques that can be practiced to maintain emotional stability between sessions.

8. Reevaluation. Each new session is started by evaluating the client's progress. First, the client will be asked to focus on targets that have been achieved.
The therapist will review the client's responses to see if the client is successful in maintaining positive results. The therapist will ask how the client feels with the previous target and will examine disruptions occurring between sessions. From this examination, the therapist will determine whether to pursue new targets or go back to previous ones to engage in additional reprocessing and integration.

Unlike existing studies, the current study will evaluate how EMDR works from the neuropsychological approach of treating PTSD. Theoretically, examining the neuropsychological side of EMDR therapy is important because it can be used as a base to modify future EMDR therapies, so that future EMDR therapies can be made more effective. The process of treating PTSD is also very important and necessary considering the high risk factor enabling people to experience PTSD, especially in Indonesia where, geographically and geodynamically, the nation is prone to natural disasters. Such considerations warrant the need to effectively treat PTSD on victims following the occurrence of natural disasters.

\section{Method}

The design of the current study is a one group pretest-posttest design which is a research design measuring behavior before and after treatment. Five participants with PTSD are given EMDR therapy treatment. The pretest condition is done to measure the initial PTSD symptoms of the participants. Next, participants will in turn be given four EMDR therapy sessions, consisting of eight stages: Client history, preparation, assessment, desensitization, installation, closure, and reevaluation. Posttest is done once participants finish all the sessions. Results from the EMDR therapy will be tested for significance using paired difference Wilcoxon test. This test is aimed to examine whether there are any significant differences in the scores between pretest (before the EMDR therapy) and posttest (after the EMDR therapy).

The EMDR therapy is given approximately 60-90 minutes. Each session is done within the same procedure. For the first session, each stage of the procedure is done while for the following sessions (Sessions 2 until 4) the process starts from Stage 2 (preparation) followed until Stage 7 (closure), while initially conducting the re-evaluation stage to gauge the participant's progress. One therapy session is done in a period of one week, thus a total period of four weeks is needed to fully complete the EMDR therapy. 
Table 1

Research Design

\begin{tabular}{lcccc}
\hline Group & Week & Pretest $(\mathrm{Y} 1)$ & Treatment $(\mathrm{X})$ & Posttest $(\mathrm{Y} 1)$ \\
\hline 9 participants & 1 & Pretest & & \\
& 2 & & Session 1 & Evaluation \\
& 3 & Session 2 & Evaluation \\
& 4 & Session 3 & Evaluation \\
& 5 & Session 4 & Evaluation \\
& 6 & & & Posttest \\
\hline
\end{tabular}

Variables in this research consist of EMDR therapy as the independent variable and PTSD symptom as the dependent variable. The operational definitions of the two variables are as follows:

a. EMDR therapy is a bilateral eye movement stimulation based on eight main EMDR procedures given to victims of natural disasters.

b. PTSD symptoms are PTSD symptoms before and after EMDR therapy consisting of re-experiencing, avoidance, and hyperarousal symptoms.

There are other extraneous variables that can affect the results of therapy, however these are difficult to control during the therapy. Such non-controllable extraneous variables include social support received by participants during the therapy and participant's family problems. Extraneous variables that can still be controlled in this therapy include: therapy rooms that are free from noise or outside intervention. Intervening variables that can disrupt the process of the therapy include: anxiety and motivation of participants to recover. Table 1 describes the research design.

\section{Participants and Measurement}

Consecutive sampling method was used to gather participants, where participants in this study are chosen based on a criteria made by the researcher, according to their availability in the field (Graziano $\&$ Raulin, 2000). Participants in this study are people who experienced traumatic incident in the form of an avalanche in Cililin area, West Java (Participants 1-5) and earthquake in Pangalengan, West Java (Participants 6-9). At the time of therapy, participants indicated that they have been experiencing traumatic incidents 1-2 years after the event. The criteria for the participants in this study are: adults aged 1956 years old, diagnosed with PTSD according to DSM IV-TR (2000), referred to undergo psychotherapy treatment after the traumatic incident, not currently consuming medicinal drugs and not forced to undergo the treatment during data collection. The therapy procedure has received ethical clearance from Komite Etik Penelitian Kesehatan (KEPK)-RS. Hasan Sadikin.

Measurement of pretest and posttest condition from participants is done by using PSS (PTSD Symptom Scale) questionnaire, supported with assessment results from the EMDR therapy procedure to understand the initial condition felt by participants before and after EMDR therapy is given. Interviews are conducted at the conclusion of the EMDR therapy to further illustrate the psychological condition of each participant.

\section{Results}

\section{Participant Characteristics}

Nine people participated in this study (nine male and seven female). Their characteristics are presented in Table 2. From Table 2, it can be seen that participants are those who are aged 30-50, married, Sundanese, educated in the elementary school to high school level, with seven participants experiencing moderate PTSD and two experiencing severe PTSD. A moderate level of PTSD is characterized as reexperiencing, avoidance, and hyperarousal that are experienced quite frequently in a span of one week. A severe level of PTSD is characterized as re-experiencing, avoidance, and hyperarousal that are experienced very frequently in a span of one week.

\section{Statistical Testing}

In this study, a Wilcoxon statistics test is used (Table 3) to test the significance of a comparative hypothesis involving two paired samples with ordinal data. It was hypothesized that:

H0: There is no significant difference between PTSD symptom scores before and after EMDR therapy. 
Table 2

Demographic Profile of Participants

\begin{tabular}{lcccllcc}
\hline No & Participants & Sex & Age & Status & Ethnicity & Education (School) & PTSD Symptom \\
\hline 1 & AS & Male & 45 & Married & Sundanese & Middle school & Severe \\
2 & OJ & Male & 45 & Married & Sundanese & Elementary & Moderate \\
3 & EK & Female & 43 & Married & Sundanese & Elementary & Severe \\
4 & ER & Female & 39 & Married & Sundanese & Elementary & Moderate \\
5 & AA & Female & 44 & Married & Sundanese & Year 2 Elementary & Moderate \\
6 & AT & Female & 31 & Married & Sundanese & Middle school & Moderate \\
7 & LL & Female & 42 & Married & Sundanese & High school & Moderate \\
8 & TK & Female & 48 & Married & Sundanese & High school & Moderate \\
9 & RS & Female & 35 & Married & Sundanese & High school & Moderate \\
\hline
\end{tabular}

Table 3

Wilcoxon Test of Pre- and Post- Treatment Score for PTSD Using SPSS Version 20.0

\begin{tabular}{|c|c|c|c|c|}
\hline & & $N$ & Mean Rank & $\begin{array}{c}\text { Sum of } \\
\text { Ranks }\end{array}$ \\
\hline & Negative Ranks & $9^{\mathrm{a}}$ & 5.00 & 45.00 \\
\hline Post- & Positive Ranks & $0^{\mathrm{b}}$ & .00 & .00 \\
\hline \multirow[t]{2}{*}{ Pre } & Ties & $0^{\mathrm{c}}$ & & \\
\hline & Total & 9 & & \\
\hline
\end{tabular}

Tabel 3A

Test Statistics ${ }^{a}$

\begin{tabular}{lr} 
& Post - Pre \\
\hline$Z$ & $-2.668^{\mathrm{b}}$ \\
Asymp. Sig. (2-tailed) & .008 \\
\hline Note. a. Wilcoxon Signed Ranks Test; b. Based on positive ranks
\end{tabular}

Table 4

Mean Scores and Standard Deviation of PTSD Scores

\begin{tabular}{lccccc}
\hline & $N$ & Min & Max & Mean & $\begin{array}{c}\text { Std. } \\
\text { Deviation }\end{array}$ \\
\hline Pre & 9 & 23.00 & 37.00 & 30.8889 & 4.64878 \\
Post & 9 & 5.00 & 24.00 & 15.7778 & 6.30035 \\
Valid $N$ & 9 & & & & \\
(listwise) & & & & & \\
\hline
\end{tabular}

H1: There is a significant difference between PTSD symptom scores before and after EMDR therapy.

If the Asymp Value. Sig. $<\alpha$, then H0 is rejected; if the Asymp Value. Sig. $>\alpha$, then HO is accepted. From Table 3A, it can be seen that the $Z$ score is $2.668 \mathrm{~b}$ with Asymp. Sig. $=.008$. From the score of Asymp. Sig. $=.008<.05, \mathrm{H} 0$ is rejected. This means that there is a significant difference between scores before and after EMDR therapy is administered.

From Table 4, the mean scores before and after the EMDR intervention are 30.88 and 15.77 respectively. This showed that the PTSD symptom scores are reduced after EMDR therapy is administered.

\section{Results of PTSD Symptoms Measurement}

The following is the result of PSS scores done before and after EMDR is given to participants suffering from PTSD due to avalanche.

From Figure 2, it can be seen that PTSD symptoms are reduced on all nine participants. The decrease can be seen based on the resulting scores and percentage decrease of PTSD symptoms. Based on Table 3, the difference between pre- and post- scores, it is shown that the largest decrease occurred in participant AT (78.26\%) followed by participant LL $(67.74 \%)$. The least amount of decrease of PTSD symptoms occurred on participant OJ (26.67\%).

From Table 5, it can be seen that one participant experienced a decrease from severe PTSD to mild, one participant experienced a decrease from severe PTSD to moderate, and four participants experienced a reduction from moderate PTSD to mild PTSD. Three other participants did not experience a change in PTSD category, however their symptom score showed a decrease.

\section{EMDR Therapy Result}

EMDR therapy was administered to nine participants, each with four EMDR sessions lasting approximately 60 minutes. The following is the initial assessment results from the first session of EMDR therapy.

Table 6 illustrates the assessment results of participants prior to the EMDR therapy. Participants experienced deep subjective emotions toward the disaster. This can be seen from the high baseline SUD (Subjective Units of Disturbance) score, mostly around 6 and 7 (on a scale of 0-10). This means that participants still feel negative emotions such as fear, sadness, irritability related to the traumatic incident. Based on baseline VoC (Validity of Cognition) scale, scores were found to be around 2-5 (on a scale of 0-7). This indicated that participants have not yet deve- 
Table 5

Reduction of PTSD Symptoms using PSS Questionnaire

\begin{tabular}{cccccc}
\hline \multirow{2}{*}{ No } & Participant & Pre & Therapy & $\begin{array}{c}\text { Amount } \\
\text { Reduced }\end{array}$ & Symptom Reduced (\%) \\
\hline 1 & AS & $37(\mathrm{~B})$ & $24(\mathrm{M})$ & 13 & 35.13 \\
2 & OJ & $30(\mathrm{M})$ & $22(\mathrm{M})$ & 8 & 26.67 \\
3 & EK & $36(\mathrm{~B})$ & $16(\mathrm{R})$ & 20 & 55.56 \\
4 & ER & $30(\mathrm{M})$ & $20(\mathrm{M})$ & 10 & 33.33 \\
5 & AA & $32(\mathrm{M})$ & $16(\mathrm{R})$ & 16 & 50.00 \\
6 & AT & $23(\mathrm{M})$ & $5(\mathrm{R})$ & 18 & 67.26 \\
7 & LL & $31(\mathrm{M})$ & $10(\mathrm{R})$ & 21 & 60.00 \\
8 & TK & $25(\mathrm{M})$ & $10(\mathrm{R})$ & 15 & 44.11 \\
9 & RS & $34(\mathrm{M})$ & $19(\mathrm{M})$ & 15 & \\
\hline Note. & Mild category (R): score $(0-17) ;$ Moderate category (M): score (18-34); Severe category (B): score (35-51).
\end{tabular}

PSS Scores Before and After EMDR Therapy

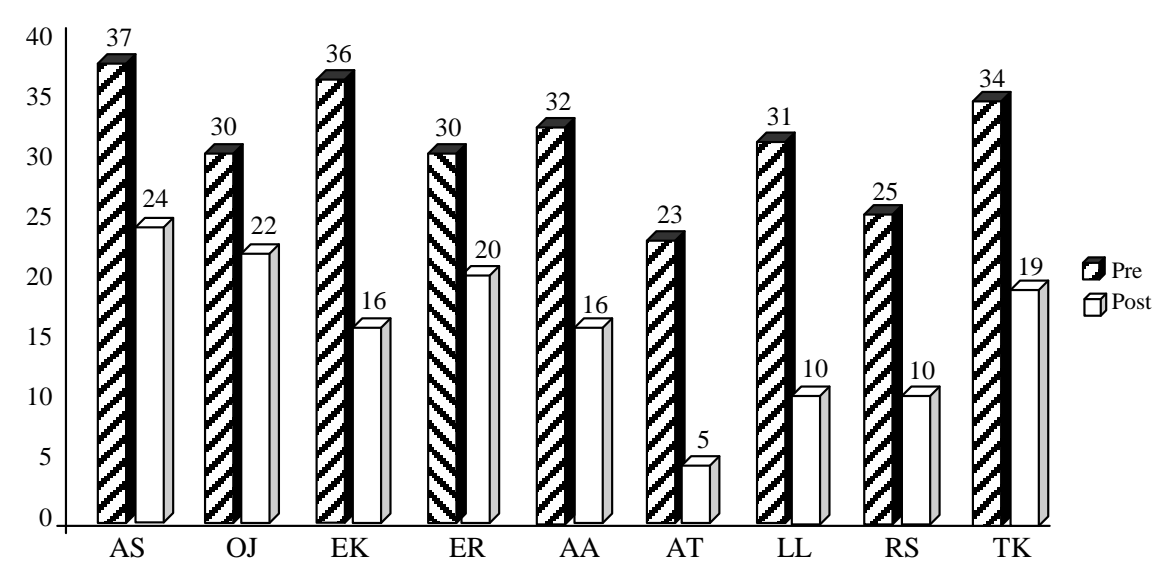

Figure 2. PTSD symptoms measurement before and after EMDR therapy.

loped positive beliefs and perceptions when faced with traumatic incidents.

On the fourth EMDR therapy session, each participant stated to have experienced change. Their baseline SUD scores decreased to a range of 2-4. This indicates that the level of emotional distress experienced by participants such as fear, irritability, dread, and sadness when facing traumatic stimulus is getting closer to 0 . On the other hand, baseline VOC scores increased to a maximum of 6-7, indicating the level of positive beliefs such as patience, strength, and belief to face the event reached the maximum level (7). Related to physical sensations, participants indicated a reduction compared to their initial state prior to the EMDR therapy. However, participants EK and RS stated that they still felt physical sensetions when faced with traumatic stimulus. This showed that the presence of traumatic stimuli may still trigger negative feelings; however such feelings are activated on a much lower intensity compared to the state prior to the EMDR therapy.

\section{Discussion}

Statistical testing showed that there is a significant difference between the scores of pre- and postEMDR therapy on PTSD. Statistical analysis is also supported by descriptive data, which indicated that the mean score of PTSD symptoms after EMDR therapy is significantly lower to the mean score before the EMDR therapy. Although not all PTSD symptoms were completely resolved, the interview results indicated that the EMDR therapy has helped participants to relieve some of their psychological burden. They are more able to willingly accept the loss of their family members to the natural disaster.

Changes in PTSD symptom can be explained through the applied principles in EMDR therapy. Eye movement used in EMDR triggers a physiological mechanism that activates the information processing system. At the same time, recalling a traumatic incident is done internally along with reprocessing of event and release of negative emotions to 
Table 6

Assessment of the First EMDR Therapy Session

\begin{tabular}{|c|c|c|c|c|c|c|c|}
\hline \multirow{2}{*}{ No } & \multirow{2}{*}{ Participant } & \multicolumn{6}{|c|}{ Stage 2 EMDR therapy assessment } \\
\hline & & $\mathrm{NC}$ & PC & VOC & Emotion & SUD & Body scan \\
\hline 1 & AS & Powerless, weak & $\begin{array}{l}\text { Strong and } \\
\text { steadfast }\end{array}$ & 3 & $\mathrm{Sad}$ & 6 & Restless \\
\hline 2 & OJ & Powerless & Strong & 2 & Sad, scared & 6 & Head is heavy, dizzy \\
\hline 3 & EK & Powerless, weak & Strong & 4 & Sad, scared & 6 & $\begin{array}{l}\text { Restless. limp, } \\
\text { headache }\end{array}$ \\
\hline 4 & ER & Powerless & $\begin{array}{l}\text { steadfast, } \\
\text { strong }\end{array}$ & 5 & $\begin{array}{l}\text { Sad, scared, } \\
\text { irritated }\end{array}$ & 5 & Restless, dizzy \\
\hline 5 & AA & $\begin{array}{l}\text { Finds it hard to } \\
\text { believe, weak }\end{array}$ & $\begin{array}{l}\text { Believe, } \\
\text { steadfast }\end{array}$ & 4 & Sad & 6 & $\begin{array}{l}\text { Restless. heart beats } \\
\text { fast }\end{array}$ \\
\hline 6 & AT & Powerless & $\begin{array}{l}\text { steadfast, } \\
\text { strong, and } \\
\text { calm }\end{array}$ & 3 & Sad, scared & 7,5 & $\begin{array}{l}\text { Heart beats fast, stiff, } \\
\text { cold hands }\end{array}$ \\
\hline 7 & LL & $\begin{array}{c}\text { Scared of } \\
\text { separation, } \\
\text { powerless }\end{array}$ & $\begin{array}{l}\text { Survive, } \\
\text { steadfast }\end{array}$ & 3,5 & Sad, scared & 6 & $\begin{array}{l}\text { Limp body, heart beats } \\
\text { fast, stiff }\end{array}$ \\
\hline 8 & TK & Powerless, weak & $\begin{array}{l}\text { Strong, } \\
\text { steadfast }\end{array}$ & 4 & $\begin{array}{l}\text { Sad, scared, } \\
\text { afraid }\end{array}$ & 6 & $\begin{array}{l}\text { Limp body, heart beats } \\
\text { fast }\end{array}$ \\
\hline 9 & RS & $\begin{array}{l}\text { Feels in danger, } \\
\text { powerless }\end{array}$ & $\begin{array}{l}\text { Survive, } \\
\text { strong }\end{array}$ & 3 & Sad, scared & 7 & $\begin{array}{l}\text { Limp body, heart beats } \\
\text { fast }\end{array}$ \\
\hline
\end{tabular}

Note. NC: Negative Cognition; PC: Positive Cognition; VoC: Validity of Cognition

create positive beliefs. Choosing a conscious belief with eye movements will facilitate the connection process of nerve networks, establishing a mechanism of insight and integration. This is further supported by EMDR therapy data showing an increase of $\mathrm{VoC}$ scores on the fourth session, pointing at the range of 6-7.

Based on the transfer and integration model of episodic memory, (Stickgold, 2002) the integration process is stated to occur when the stored memory of an event in the hippocampus system connected with the limbic system has been successfully transferred into a network of semantic memory in the neocortex. In the participants' case, traumatic incident in the form of an avalanche has been recorded to their memory. Various memories, all having negative impacts on the participants, were stated by the participants: seeing falling boulders crashing into houses, hearing the sound of the rain falling rocks, seeing the bodies of children, and other voices. Those memories are episodic memories that can at times appear as dreams or daily flashbacks. The presence of an amygdala connected to the hippocampus in the limbic system strengthens fear. Thus, participants feel sad, scared, or irritated when experiencing similar target memories.

In the desensitization stage, reprocessing starts by using bilateral eye movement stimulation. Participants try to recall the incident internally and simultaneously reprocess of the event. They were asked to concentrate on the avalanche while silently stating the negative cognitions attributed to the incident. At the same time, they were asked to feel which body part they think is experiencing a level of discomfort. This is done to identify, reprocess, and release disruptive memory associated with the earthquake and everything related to it (image, thoughts, emotions, physical sensations related to avalanche or earthquake) so that the impact of the negative memory will be reduced. Reprocessing helps participants to learn to understand the incident and to weaken episodic memory which in turn will reduce felt negative emotions. Data from the therapy process showed that a majority of emotions such as fear and sadness decreased in time, indicated by the baseline score getting closer to 0 , in the range of 3-4.

EMDR produces emotional and physiological changes, making participants more relaxed, including the occurrence of breathing synchronization and the slowing of heart rate. This finding is supported by the study done by Maxfield et al. (2008) who explained that when clients are doing the eye movement and simultaneously focusing on the image, the quality of the image will reduce, and therefore the level of fear and emotion will be maintained at a lower level.

The installation stage occurs following a complete integration between participant's positive self-assessment and the target incident. This stage is done to 
increase positive cognition related to the incident. In this study, participants attempted to related positive cognition (e.g.: I am steadfast and sincere, I am firm in facing this challenge) with the avalanche they experienced. During installation, progress occurs in the form of how participants feel towards the incident. New understandings are formed during reprocessing, and these understandings differ significantly from what participants initially thought; they now view the incident with a more positive outlook. When asked about the incident, participants are encouraged to accept or change their view into something more positive. When participants reach a VoC score of 7, this indicates that the eye movement stimulation have successfully taken effect. It also shows that integration has occurred on semantic memory, providing insight on the parti-cipants to learn and realize that they are able to face and go through the avalanche (positive cognition).

The process of EMDR therapy is influenced by numerous internal and external factors. Some internal factors identified in this study are: fear and anxiety that are always felt by participants regarding the possibility of avalanche or natural disaster. This is considering the fact that their residence is prone to future avalanches. On the other hand, external factors such as financial limitations also influence the process of the therapy. Participants have yet to receive financial aid from the government since the avalanche in March 2013. Furthermore, problems arising between therapy sessions can add to participant's mental burden, emotional instability, and physical health.

\section{Conclusion}

Based on the Wilcoxon test, a $Z$-score of - 2.668 $(p<.05)$ is acquired with Asymp. Sig. $=.008$. Therefore, $\mathrm{H} 0$ is rejected which means that there is a significant difference between PTSD symptom scores before and after the EMDR therapy. From the current study, it can be concluded that a decrease of PTSD symptoms occurs on all participants after EMDR was administered. It can further be stated that EMDR therapy can decrease PTSD symptoms.

From the interview results, factors inhibiting the effectiveness of the process of therapy were identified. These include fear and anxiety over the possibility of reoccurrence of the avalanche or natural disasters. This is in considering the fact that the participants reside in disaster prone areas. Additionally, factors such as financial limitations also became a mental burden on the participants during the therapy.

\section{References}

American Psychiatric Association (2000). Diagnostic and Statistical Manual of Mental Disorder (DSMIV, 4th ed.). DSM-IV. Washington, DC: Author.

Bisson, J. \& Andrew. 2009. Psychological treatments of post traumatic stress disorder (PTSD). Review. The Cochrane Library, 2009. (2) 5 August 2011. Accessed from http://www.theco-cochrane.com

Brown, L. A., \& Wesley, R. (2013). Visual working memory is enhanced by mixed strategy use and semantic coding. Journal of Cognitive Psychology, 25(3), 328-338. DOI:10.1080/20445911.2013.773004

Graziano, A. M. ,\& Raulin, M. L. (2000). Research methods: A process inquiry (4th ed.). Boston: Allyn and Bacon.

Hensley, B. J. (2009). An EMDR primer: From practicum to practice. New York, NY: Springer Publishing Co.

Ironson, G. I., Freund, B., Strauss, J. L., \& Williams, J. (2002). Comparison of two treatments for traumatic stress: A community-based study of EMDR and prolonged exposure. Journal of Clinical Psychology, 58, 113-128.

Maxfield, L., Melnyk, W. T. \& Hayman, C. A. G. (2008). A working memory explanation for the effects of eye movements in EMDR. Journal of EMDR Practice and Research, 2(4), 247-261.

Nacash, N., Foa, E. B., Fostick, L., Polliack, M., Dinstein, Y., Tzur, D., ..., \& Zohar, J. (2007). Prolonged exposure therapy for chronic combat-related PTSD: A case report of five veterans. CNS Spectrums, 12(9), 690-695.

Raboni, M. R., Tufik, S, \& Sucheki, D. (2006). Treatment of PTSD by eye movement desensitization and reprocessing (EMDR) improves sleep quality, quality of life and perception of stress. Annual New York Academy of Sciences, 1071, 508-513.

Shapiro, F. (1995). Eye movement desensitization and reprocessing: Basic principles, protocols, and procedures. New York: The Guilford Press.

Shapiro, F., (2002). Paradigms, processing, and personality development. In F. Shapiro [Ed.]. EMDR as an integrative psychotherapy approach: Experts of diverse orientations explore the paradigm prism. Washington, D.C.: American Psychological Association Books.

Stickgold, R. (2002). EMDR: A putative neurobiological mechanism of action. Journal of Clinical Psychology, 58(1), 61-75.

Susanty, E., Albanik, H., \& Prathama, A.G. (2012). The effectiveness of the eye movement desensitization and reprocessing (EMDR) therapy in handling post 
traumatic stress disorder (PTSD) the housewives earthquake survivor, in Pangalengan district, West Java. Proceeding, ISBN 978-983-2641-93-3 SEAP,
Sabah Malaysia, September 2012.

Taylor, S.E. (2006). Health psychology (6th ed.). New York: McGraw Hill International USA. 